\title{
Radiometric Determination of the Temperature of Mars in I924.
}

By Dr. W. W. Coblentz, Bureau of Standards, Washington, D.C.

$\mathrm{T}^{\mathrm{H}}$ $\mathrm{HE}$ main problem in the radiometric programme of 1924 at the Lowell Observatory, as stated in the article in NatURE of September 19, p. 439, was the measurement of the radiation from Mars. For this purpose most of the measurements were made at the 640-inch focus of the 40-inch Lowell reflector, which gave an image of the disc of Mars about $2 \mathrm{~mm}$. in diameter. The receiver of the vacuum thermocouple was $0.23 \mathrm{~mm}$. in diameter, or about $\frac{1}{\mathrm{x}}$ of the diameter of the disc of Mars at opposition. This permitted the isolation of small areas on the disk of the planet and revealed hitherto unobserved and perhaps unexpected temperature conditions.

By means of a series of screens of water, quartz, glass, and fluorite, the radiation emanating from a planet, e.g. Mars, was separated into spectral components and the radiation intensities determined in the observed Martian water-cell transmissions (W.C.T.'s in Table I); (2) by the law of spectral radiation and the ratio of the Martian spectral radiation components, A : B ; (3) by plotting Very's observed lunar temperatures against the observed lunar spectral radiation components, A : B, and extrapolating to the observed ratios of the Martian components ; (4) by calculating the lunar temperatures (Menzel) from the lunar watercell transmissions, using the fourth power law, plotting these temperatures against the observed lunar spectral radiation components, $\mathrm{A}: \mathrm{B}$, and extrapolating to the observed ratios of the Martian spectral radiation components ; and (5) by plotting the lunar temperatures (which were obtained by calculation from the lunar water-cell transmissions, using the fourth power law) against the observed lunar water-cell transmissions and extrapolating to the observed Martian water-cell trans-

Table I.-Mars: Comparison of Temperatures on the Apparent Centre of the Disk as obTained by Various Methods.

\begin{tabular}{|c|c|c|c|c|c|c|c|c|c|}
\hline \multirow{3}{*}{$\begin{array}{l}\text { Date } \\
\text { I924. }\end{array}$} & \multirow{3}{*}{$\begin{array}{l}\text { Water-cell } \\
\text { Irans- } \\
\text { mission } \\
\text { (W.C.T.). }\end{array}$} & \multirow{3}{*}{$\begin{array}{l}\text { Spectral } \\
\text { Com- } \\
\text { ponents } \\
\text { (A: B). }\end{array}$} & \multicolumn{5}{|c|}{ Temperatures, ${ }^{\circ} \mathrm{C}$. Method. } & \multirow{3}{*}{ Mean. } & \multirow{3}{*}{ Region on Mars. } \\
\hline & & & \multicolumn{2}{|c|}{ Black Body. } & \multicolumn{3}{|c|}{ Moon. } & & \\
\hline & & & $\begin{array}{c}\mathbf{r} \\
\text { Menzel } \\
\text { (W.C.T.). }\end{array}$ & $\begin{array}{c}2 \\
(A: B) .\end{array}$ & $\begin{array}{c}3 \\
\text { Very } \\
(\mathrm{A}: \mathrm{B})\end{array}$ & $\begin{array}{c}4 \\
\text { Menzel } \\
(\mathrm{A}: \mathrm{B}) .\end{array}$ & $\begin{array}{c}5 \\
\text { (W.C.T.). }\end{array}$ & & \\
\hline Aug. & & & & & & & & & \\
\hline $\begin{array}{r}6 \\
14\end{array}$ & $\begin{array}{l}33 \cdot 5 \\
30 \cdot 5\end{array}$ & $\begin{array}{l}4 \mathrm{I} \cdot 7 \\
4 \mathrm{I} \cdot 3\end{array}$ & $\begin{array}{r}-1 \\
9\end{array}$ & $\begin{array}{l}\text { I2 } \\
\text { I0 }\end{array}$ & $\begin{array}{l}x_{4} \\
\mathrm{I}_{3}\end{array}$ & $\begin{array}{l}\text { I2 } \\
\text { II }\end{array}$ & $\begin{array}{r}2 \\
16\end{array}$ & $\begin{array}{r}8 \\
12\end{array}$ & $\begin{array}{l}\text { Syrtis Major. } \\
\text { Mare Sirenum. }\end{array}$ \\
\hline 15 & $32 \cdot 4$ & $43 \cdot \bar{I}$ & 5 & $2 \mathrm{I}$ & r8 & I4 & 8 & I3 & , \\
\hline 18 & $3 I \cdot \mathbf{I}$ & $38 \cdot 6$ & 4 & -5 & 8 & 7 & I3 & 6 & ", \\
\hline $2 I$ & $32 \cdot 5$ & $40 \cdot 7$ & 3 & 6 & I2 & Io & 6 & 7 & Quing" mainn puth of \\
\hline $2 \mathrm{I}$ & $34^{\circ} 9$ & $39 \cdot I$ & -5 & -3 & 6 & 8 & -7 & o & $\begin{array}{l}\text { Bright region north of Mare } \\
\text { Sirenum. }\end{array}$ \\
\hline 23 & $32 \cdot 8$ & $36 \cdot 6$ & 2 & -20 & 3 & 4 & 4 & $-I$ & " " " " \\
\hline 25 & $33 \cdot 7$ & $38 \cdot 3$ & -7 & -8 & 7 & 6 & 2 & $-I$ & $\begin{array}{l}\text { Bright region north of Beak } \\
\text { of Sirens. }\end{array}$ \\
\hline $\begin{array}{l}28 \\
\text { Sept. }\end{array}$ & $3 I \cdot 2$ & $50 \cdot 0 ?$ & 4 & $55 ?$ & 32 & 24 & $\mathrm{x} 2$ & $\mathrm{x} 8$ & Solis Lacus. Poor seeing. \\
\hline II & $30 \cdot 8$ & $47 \cdot 8$ & I & 45 & 26 & 20 & $x_{5}$ & 22 & Syrtis Major. \\
\hline I3 & $29 \cdot 6$ & $39 \cdot 3$ & 6 & -2 & Io & 8 & 22 & 9 & -0 font for \\
\hline 13 & $25 \cdot 1$ & $55^{\circ} 8 ?$ & 22 & . & 42 & 32 & . & 32 & I8.4 foot focus. \\
\hline I 4 & $29 \cdot 3$ & $46 \cdot 4$ & 6 & 40 & 22 & I8 & 25 & 22 & Mare Cimmerium. \\
\hline
\end{tabular}

spectral regions of 0.03 to $I \cdot 4 \mu, \mathrm{I} \cdot 4$ to $4 \cdot \mathrm{I} \mu, 4 \cdot \mathrm{I}$ to $8 \mu$, 8 to $12.5 \mu$, and 12.5 to $I_{5} \mu$. In this paper the ratios of the spectral components of the planetary radiation at 8 to $\mathrm{I2.} 5 \mu$ and at $\mathrm{I}_{2} .5$ to $\mathrm{I}_{5} \mu$ (A : B) are of special interest. The radiometric work was carried out in collaboration with $\mathrm{Mr}$. C. O. Lampland, and the complete results are given in the June and July issues of the Journal of the Franklin Institute.

In view of the conflicting opinions regarding temperature conditions on Mars, it was desirable to reduce the radiometric data by various methods and also to have someone not connected with the work to make some of the calculations. The writer therefore submitted to Dr. D. H. Menzel a considerable portion of the observations obtained in 1924 for calculation, thus supplementing the work of I922, as mentioned in NATURE of September I9.

Martian temperatures were derived by the following methods : (I) by the fourth power law of black body radiation (Menzel), using Russell's formula and the missions. (A more complete discussion is given in the Astronomische Nachrichten, June 1925.)

In addition to these calculations, planetary temperatures were inferred from comparisons with the earth, in which it is shown that the temperature of the solid surface of Mars would be expected to rise almost as high as that of the earth. In fact, with much clearer skies and with less air convection in some of the darker places on Mars, especially in the temperate and in the frigid zones, where the insolation is so prolonged, the temperature should be considerably higher than observed on similar regions of the earth.

The temperatures derived by these various methods of reducing the data are in good agreement and indicate conclusively that the equatorial temperature of Mars, at perihelion, was considerably above $0^{\circ} \mathrm{C}$. When one considers the difficulty in establishing the temperature of a terrestrial object within $10^{\circ} \mathrm{C}$., it seems truly remarkable that these various methods appear to be so close in agreement in indicating that the temperature NO. 29 I7, vOL. I I6] 
of Mars rises above $0^{\circ}, \mathrm{C}$. This is an extremely important deduction, for the possibility of vegetable life on Mars depends partly upon the question of temperature conditions.

A weakness in the method of using the spectral components is owing to the fact that the spectral range of the planetary radiation is narrow, and the spectral transmissions of the atmosphere and of the fluorite screen at Io to II $\mu$ are not known with sufficient accuracy to determine the temperatures to better than $10^{\circ} \mathrm{C}$. However, it is a new and an independent method for obtaining temperature levels.

Ordinarily it would be considered sufficiently close to have determined the temperature level to within $10^{\circ} \mathrm{C}$. However, in the present problem the temperature estimates range about $0^{\circ} \mathrm{C}$., and the question at issue is whether the average estimates place the value somewhat above $0^{\circ} \mathrm{C}$., for the question of the possibility of vegetation on Mars depends partly upon this temperature estimate. While the results obtained by this method give a wider range of temperatures than the other methods, its usefulness in supplementing the other methods seems evident.

The dark regions were found to be hotter than the bright regions ; also the east limb or sunrise side was observed to be cooler than the west limb or afternoon side of the planet. The temperatures of the bright areas range from $-10^{\circ}$ to $5^{\circ} \mathrm{C}$., while the temperatures of the dark areas range from $10^{\circ}$ to $20^{\circ} \mathrm{C}$., or perhaps even higher. The average temperature of the apparent centre of the disk, including the bright and the dark areas, was found to be about $15^{\circ} \mathrm{C}$., verifying the estimate of $10^{\circ}$ to $20^{\circ} \mathrm{C}$. based upon the radiometric measurements of 1922 . There was but little seasonal change in temperature (average $14^{\circ} \mathrm{C}$.) on the centre of the disk during the six weeks from August I to September 14 . While the measurements were in progress it was winter in the north polar regions. Under these conditions the temperature of the irradiated north polar region was down to $-70^{\circ} \mathrm{C}$., or perhaps even lower, and continued at this temperature during the course of our measurements. Similar temperatures occur in our arctic regions during the winter. On the southern hemisphere it was early summer, and the temperature of the south polar region, as observed through the overhanging atmospheric mantle of mist or perhaps ice spicules, was $-60^{\circ} \mathrm{C}$. However, in view of the fact that it was the summer season, with melting snow and a receding polar cap, it is reasonable to assume that the temperature of the solid surface at the south pole was up to $0^{\circ} \mathrm{C}$. The complete paper by Coblentz and Lampland in the Jour. Franklin Institute (June and July 1925 ) gives data on climatic conditions on various parts of the surface of Mars: (I) the bright and dark regions on the centre of the disk; (2) the east and west limbs; and (3) the north and south polar regions.

To the writer the apparent temperature of $-60^{\circ} \mathrm{C}$., as measured through the water cell during the early Martian summer in the south polar region, is not inconsistent with the commonsense interpretation of the visual observations (receding polar cap, melting ice) indicating a temperature up to $0^{\circ} \mathrm{C}$., but is a remarkable verification of the presence of an atmosphere containing a mantle of ice spicules or perhaps water vapour
(" mist"), which prevents the escape of planetary; radiation from the solid surface. It is to be noted that our interpretation of planetary temperatures is based upon the radiation of wave-lengths 8 to $I_{5} \mu$ which emanates from the planet. Evidently this overhanging mantle is of considerable extent and is perhaps in the form of a thick mist or fog which is opaque to these wave-lengths. For it is well known that the highly attenuated water vapour in our atmosphere is quite transparent to radiation of wave-lengths 8 to ${ }_{5} \mu$, whereas mist and fog prevent the transmission of infra-red rays of long wave-length.

The temperature of the south polar cap changed but slowly during July and August. However, in September the temperature began to rise rapidly, and by October the water-cell transmissions decreased to 30 per cent. or even lower, indicating a temperature of $6^{\circ} \mathrm{C}$. (true temperature about $15^{\circ} \mathrm{C}$.). This is extremely interesting in view of Rev.T. E. R. Phillips' recent paper on this subject (Mon. Notices R.A.S., 85, p. 179, 1924), in which micrometric measurements are given showing that the melting of the snow proceeded slowly during July, but that the cap diminished rapidly in size during August and September, and became very small in November.

This rapid rise in temperature of the south polar region from $-60^{\circ}$ (the temperature of the isothermal layer of the polar canopy; $0^{\circ} \mathrm{C}$. if interpreted from the visual observations of the receding cap of melting ice) in July to $10^{\circ} \mathrm{C}$. or even higher at the Martian summer solstice (on October 5) is perhaps one of the most important results of this investigation. From a consideration of the prolonged insolation on the south polar region, such a temperature rise is to be expected.

On the west limb the observed temperature was $-2^{\circ}$ to $-8^{\circ} \mathrm{C}$. at the beginning of August, when there was a small dark phase. When there was no dark phase on the west limb the temperatures ranged from $0^{\circ}$ to $6^{\circ} \mathrm{C}$.

Perhaps the most interesting series of measurements relate to the east limb or sunrise side of the planet. During the first part of August, the east limb was irradiated for an hour or more before turning into view. Under these conditions the observed temperatures of the eastern limb range from $-10^{\circ}$ to $-20^{\circ} \mathrm{C}$. At opposition, August 22, when there was no dark phase, the temperature was down to $-45^{\circ} \mathrm{C}$. At the conclusion of the series at the 53.3 foot focus, on September 12 , when the dark phase was barely perceptible on the east limb (illuminated surface 0.976 ), the temperature was $-60^{\circ} \mathrm{C}$. How much lower the temperature falls, and whether this very low temperature is owing to setting the receiver on the atmospheric envelope, remains to be determined.

From the low temperatures recorded at the poles, and the small atmospheric envelope, it appears that the temperature of the night side of Mars may fall below $-70^{\circ} \mathrm{C}$.

This study of the seasonal changes in temperature, especially of the southern hemisphere of Mars, was continued late into November by Mr. Lampland, using the same radiometric equipment and galvanometer employed by us during the preceding months. $\mathrm{He}$ reports that the water-cell transmissions of the radiation from the north polar region continued unchanged at 
70 to 80 per cent., indicating a temperature of about $-70^{\circ} \mathrm{C}$, as was to be expected with winter on this hemisphere.

On the other hand, the water-cell transmissions of the radiation from the south polar region decreased from the high value observed in the early part of September to 30 per cent., or even lower, in November and December, indicating a temperature of $10^{\circ}$ to $15^{\circ} \mathrm{C}$., or even higher. Granting that some ice still remained at the pole, there would be a temperature gradient for which a correction should be made. On this basis, the water-cell transmissions would be still lower and the temperature of the south polar region would be higher than indicated by these measurements.

The observed high surface temperatures on Mars may be accounted for on the assumption that these dark areas contain vegetation having the properties of the tuft-forming grasses of our high prairies, and the tussock mosses and lichens of our dry tundras, which have a high absorptivity for solar radiation and a low thermal conductivity. The assumption of the presence of such a type of vegetation is in harmony with the visual observations, which show changes in the colouring of the dark areas with changes in the seasons, and it is in agreement with the lower intensity of insolation on Mars. The radiometric observations indicate that during the summer season on Mars, temperature conditions at noonday are not unlike the bright cool days on this earth, with temperatures ranging from $5^{\circ}$ to I $5^{\circ} \mathrm{C}$. or $40^{\circ}$ to $60^{\circ} \mathrm{F}$.

\section{Sir William Thiselton-Dyer and the "Flora Capensis."}

$\mathrm{T}$ HE publication in the Kew Bulletin (No. 7, I925, pp. 289-293) of an account, by Sir W. T. Thiselton-Dyer, of the commencement, progress, and completion of the "Flora Capensis," affords a fitting opportunity of recalling Sir William Thiselton-Dyer's work at the Royal Botanic Gardens, Kew, and more especially the work he has done for the British Empire in advancing the knowledge of its botanical riches in the domain both of economic and systematic botany. With regard to the systematic study of the Colonial floras, the two works which are especially associated with his many years of office at Kew are the "Flora Capensis" and the "Flora of Tropical Africa." Proposals for both these works were made by Sir William Hooker, so long ago as I863, when inter alia he put forward a proposal for a flora of the "South African Colonies" in ten volumes and a flora of the "West African Colonies" in two volumes. Out of the former proposal has come the now completed "Flora Capensis" and from the latter the "Flora of Tropical Africa," which, when finished, will occupy eleven or twelve volumes.

The "Flora Capensis," as Sir William ThiseltonDyer states, had, however, actually been commenced at the suggestion of Sir William Hooker. It was undertaken by Dr. Harvey, "sometime Treasurer of Cape Colony," the professor of botany in the University of Dublin. He "undertook to print and publish the Flora at his own risk and cost, trusting chiefly to colonial subscriptions for a repayment of the outlay." Dr. Sonder, of Hamburg, " gladly accepted Dr. Harvey's offer to share the authorship." Volume I, dedicated to Sir George Grey, K.C.B., "Governor and Commanderin-Chief of the Colony of the Cape of Good Hope," bears the publication date $1859-60$. Volume 2 was published in 1862 , and Volume 3 in 1865 . The following year Prof. Harvey died, and Dr. Sonder, who took no further part in the work, died in $188 \mathrm{r}$.

Sir Henry Barkly, Governor of the Cape of Good Hope from $1870-77$, himself an ardent naturalist and fellow of the Royal Society, urged upon Sir Joseph Hooker, who had succeeded his father as director of $\mathrm{Kew}$, the completion of the work of Harvey and Sonder, and Sir Joseph Hooker suggested to Mr. Dyer, as he then was, that he should undertake the completion of the work of the Cape Flora. As, however, he was at that time assisting Sir Joseph in sub-editing the
"Flora of British India," he was unable to entertain the proposal; and later, being appointed to the post of assistant director of Kew in 1875 , he was again precluded from taking up any particular part of the Flora himself. Sir William, however, was able to enlist the aid of numerous contributors in carrying on the work; but the general task of supervising and editing a work which was part of a project initiated by Kew, appeared to him to fall naturally within the scope of his official duty, and so after a long interval the "Flora Capensis" was again started.

Sir William points out as a striking fact, that in the volumes published by Harvey a very large number of the species are only represented by a single collection. It was highly desirable to have more copious material to work upon, if only to supply more ample data for geographical distribution, and thanks to Sir William Thiselton-Dyer a numerous body of contributors was marshalled, and they rendered valuable service in sending home material for the adequate working out of the Flora. Among these Peter MacOwan and Dr. Harry Bolus deserve particular mention.

Sir William, in his article, refers to the fact that upwards of ten thousand specimens have been named and catalogued for South African botanists and collectors in connexion with the work of the Flora, and that during twenty years, from 1877 , the time of one member of the Kew staff, Mr. N. E. Brown, was almost exclusively occupied with the determination of these fresh accessions of South African plants. Sir William bears eloquent testimony to Mr. Brown's work, pointing out that from his complete mastery of the features of the flora and of South African topography "he has been the invaluable mainstay of my own share in the undertaking."

It was in 1877 that Sir William was able to start the work on the Flora on an effective basis, and he was fortunate in being able to secure the co-operation of South African contributors, including Dr. Harry Bolus, who undertook the Ericaceæ; Dr. E. P. Phillips, who worked out the Proteaceæ; and Miss E.L. Stephens, who worked out the Penæaceæ. The Orchids, which should have been worked out by Dr. Harry Bolus, could not be carried out by him and were undertaken by the late Mr. R. A. Rolfe of the Kew Herbarium staff. Other contributors of whom Sir William makes special mention were Mr. J. G. Baker, who elaborated

NO. 29I7, VOL. I I 6$]$ 